\section{Occupational exposures and health-related quality of life in the Manaus Metropolitan Region, Amazonas State, Brazil: a cross-sectional study}

\author{
Exposições ocupacionais e qualidade de vida \\ relacionada à saúde na Região Metropolitana \\ de Manaus, Estado do Amazonas, Brasil: \\ um estudo transversal
}

\author{
Exposiciones ocupacionales y calidad de vida \\ relacionada con la salud en la región \\ metropolitana de Manaus, estado del \\ Amazonas, Brasil: estudio transversal
}

COMUNICAÇÃO BREVE

BRIEF COMMUNICATION
Gustavo Magno Baldin Tiguman 1

Monica Caicedo-Roa 1

Marcus Tolentino Silva 2

Tais Freire Galvao 1

doi: 10.1590/0102-311X00074520

\begin{abstract}
We aimed to investigate the association between occupational exposures and health-related quality of life among both informal and formal workers in the Brazilian Amazon. We conducted a cross-sectional study with working adults in the Manaus Metropolitan Region, Amazonas State, in 2015. Participants were selected through a three-step probabilistic sampling. The primary outcome was the health-related quality of life indicator, measured by the Brazilian validated version of the European Quality of Life 5-Dimensions 3-Levels (EQ-5D-3L) tool. Adjusted multivariate analysis was performed by Tobit regression and considered the complex sampling design. Results were converted to odds ratio $(O R)$. Out of the 1,910 working individuals from the sample, $60.2 \%$ were formal workers. Informal workers were significantly more exposed to occupational risks than formal workers $(p \leq 0.05)$. Mean utility score for informal and formal workers was 0.886 (95\%CI: 0.881; 0.890). Quality of life of informal workers was negatively impacted by exposure to noise $(O R=1.28$; 95\%CI: 1.13; 1.52), occupational stress $(O R=1.95 ; 95 \% C I$ : $1.65 ; 2.21)$, and industrial dust $(O R=1.46$; $95 \% C I: 1.28 ; 1.72)$, while formal workers were negatively associated with exposure to chemical substances $(O R=1.58 ; 95 \% C I: 1.28 ; 1.87)$, noise $(O R=1.40 ; 95 \% C I: 1.23 ; 1.65)$, sun $(O R=1.65 ; 95 \% C I: 1.09 ; 1.40)$, occupational stress $(O R=1.65 ; 95 \% C I: 1.46$; 1.87), biological material ( $O R=2.61 ; 95 \% C I$ : 1.72; 3.97), and industrial dust $(O R=1.46 ; 95 \% C I: 1.28 ; 1.65)$. Exposure to occupational risks among workers from the Manaus Metropolitan Region was high, affecting both informal and formal workers. Brazilian policies need to be enforced to reduce the impacts on quality of life among workers in this region.
\end{abstract}

Occupational Risks; Occupational Exposure; Occupational Health;

Quality of Life
Correspondence

G. M. B. Tiguman

Rua Cândido Portinari 200, Campinas, SP 13083-871, Brasil. gustavo.tiguman@gmail.com

1 Universidade Estadual de Campinas, Campinas, Brasil.

2 Universidade de Sorocaba, Sorocaba, Brasil. 


\section{Introduction}

It is estimated that approximately 2.3 million deaths related to occupational diseases occur every year worldwide, mainly due to cancer (32\%), work-related circulatory diseases (23\%), communicable diseases (17\%), and occupational accidents (18\%) 1.

In 2013, 154,240 cases of work-related diseases and injuries were reported in Brazil 2. Between 2008 and 2013, an increase in the proportion of informal workers among the reported cases was observed in the country 2 . Informal workers showed worse self-reported status, greater difficulty in accessing healthcare services, and less interest in seeking healthcare services when compared to formal workers in a nationwide survey from 20083.

Studies evaluating the occupational risks and quality of life for both formal and informal workers are scarce in Brazil. The aim of this study was to assess the association between occupational exposures and health-related quality of life among informal and formal workers in the Brazilian Amazon.

\section{Methods}

This was a cross-sectional population-based study conducted in the Manaus Metropolitan Region, Amazonas State, Brazil, in 20154.

This study specifically included the working population of a major survey, which selected adults ( $\geq 18$ years) through a probabilistic three-step complex sampling design 4 . Participants were divided into two categories: formal and informal workers. Formal workers are those with formal employment relationship, which guarantees labor rights and social benefits, such as vacations, maternity leave, retirement, and unemployment support 5. Informal workers are defined as individuals who develop their own economic activities and do not have any social security or formal relationships with an employer 5 .

The primary outcome was the health-related quality of life. Individual variables included: sex (male, female), age group (18-24, 25-34, 35-44, 45-59, $\geq 60$ years old), socioeconomic classification (A/B, C1, C2, D/E, where A refers to the wealthiest and E, to the poorest 6), educational level (higher education or above, high school, middle school, elementary school or less), work type (informal/formal), and occupational exposure related to work activities (work in nocturnal periods, work for more than 24 consecutive hours, exposure to chemical substances, noise, sun, radioactive material, garbage, occupational stress, biological material, industrial dust).

Health-related quality of life was assessed by the European Quality of Life 5-Dimensions 3-Levels tool (EQ-5D-3L) 7. It includes five dimensions (mobility, self-care, pain/discomfort, anxiety/depression, and usual activities). Each dimension can be scored in three levels ( $1=$ no problems, $2=$ moderate problems, and 3 = severe problems). Levels of quality of life were transformed into utility values using the conversion formula in accordance with the Brazilian valuation of EQ-5D-3L 8,9.

Data collection was performed through face-to-face interviews with trained interviewers using standardized questionnaires. The responses were registered in electronic tablets (Tab 3 SM-T110 Samsung Galaxy).

We used descriptive statistics to evaluate the sociodemographic characteristics of the working population and the results of each dimension of the EQ-5D-3L, stratified by formal and informal workers. We also calculated the means of the quality of life utility scores considering $95 \%$ confidence intervals $(95 \% \mathrm{CI})$. Multivariate analyses were performed by Tobit regression adjusted by age group, socioeconomic classification, educational level, and the complex sampling design 10 . The Tobit regression model was chosen as it is suitable for censored or bounded data that can produce ceiling effect (i.e. inability to discriminate among high levels of health status) ${ }^{11}$, such as the EQ-5D-3L utility scores 12 . The utility scores were included as the latent dependent variables in the model. Significant associations were transformed into odds ratio (OR) using the following equation: $\ln (\mathrm{OR})=\pi / \sqrt{ } 3 \times \beta^{13}$. To facilitate interpretation, the inverse of the OR was presented to indicate the association between occupational exposures and lower quality of life. Stata version 14.2 (https://www.stata.com) was used for the data analyses. 


\section{Results}

Out of the 4,001 participants of the main population-based study, 1,910 were workers, of which $60.2 \%$ were formal workers. The majority of the individuals were men (66.6\%), aged 25-44 years old (57.7\%), part of the socioeconomic classification C (middle class; 58.3\%), and with an educational level up to high school (51.8\%; Table 1). Most occupational exposures were observed among informal workers, except for exposure to the sun and working for more than 24 consecutive hours. Significant differences between informal and formal working groups were observed in the following occupational exposures: working in nocturnal periods $(\mathrm{p}<0.001)$, exposure to chemical substances $(\mathrm{p}<0.001)$, noise $(\mathrm{p}<0.001)$, sun $(\mathrm{p}<0.001)$, radioactive material $(\mathrm{p}=0.023)$, occupational stress $(\mathrm{p}=0.009)$, and biological material $(\mathrm{p}<0.001)$.

\section{Table 1}

Social, demographic, and economic characteristics of the participants $(N=1,910)$ and frequency of occupational exposures by type of work. Manaus Metropolitan Region, Amazonas State, Brazil, 2015.

\begin{tabular}{|c|c|c|c|c|c|c|}
\hline \multirow[t]{2}{*}{ Variables } & \multirow[t]{2}{*}{ Total } & \multicolumn{2}{|c|}{ Informal worker } & \multicolumn{2}{|c|}{ Formal worker } & \multirow[t]{2}{*}{ p-value ** } \\
\hline & & $\mathbf{n}$ & $\%$ * & $\mathbf{n}$ & $\%$ * & \\
\hline Sex & & & & & & 0.346 \\
\hline Male & 1,273 & 517 & 67.9 & 756 & 65.8 & \\
\hline Female & 637 & 244 & 32.1 & 393 & 34.2 & \\
\hline Age group (years) & & & & & & $<0.001$ \\
\hline $18-24$ & 274 & 154 & 20.2 & 120 & 10.4 & \\
\hline $25-34$ & 611 & 262 & 34.4 & 349 & 30.3 & \\
\hline $35-44$ & 491 & 196 & 25.9 & 295 & 25.7 & \\
\hline $45-59$ & 455 & 129 & 16.9 & 326 & 28.4 & \\
\hline$\geq 60$ & 79 & 20 & 2.6 & 59 & 5.2 & \\
\hline Socioeconomic classification $* \star \star$ & & & & & & $<0.001$ \\
\hline $\mathrm{A} / \mathrm{B}$ & 378 & 188 & 24.6 & 190 & 16.5 & \\
\hline C1 & 441 & 196 & 25.8 & 245 & 21.3 & \\
\hline $\mathrm{C} 2$ & 672 & 261 & 34.3 & 411 & 36.0 & \\
\hline $\mathrm{D} / \mathrm{E}$ & 419 & 116 & 15.3 & 303 & 26.2 & \\
\hline Educational level & & & & & & $<0.001$ \\
\hline Higher education or above & 106 & 71 & 9.4 & 35 & 3.0 & \\
\hline High school & 990 & 468 & 61.5 & 522 & 45.4 & \\
\hline Middle school & 273 & 104 & 13.7 & 169 & 14.8 & \\
\hline Elementary school or less & 541 & 118 & 15.4 & 423 & 36.8 & \\
\hline \multicolumn{7}{|l|}{ Occupational exposure } \\
\hline Work in the nocturnal period & 347 & 172 & 22.7 & 175 & 15.2 & $<0.001$ \\
\hline Work for more than 24 consecutive hours & 138 & 51 & 6.7 & 87 & 7.6 & 0.459 \\
\hline Chemical substances & 160 & 87 & 11.5 & 73 & 6.4 & $<0.001$ \\
\hline Noise & 461 & 225 & 29.6 & 236 & 20.5 & $<0.001$ \\
\hline Sun & 370 & 108 & 14.2 & 262 & 22.8 & $<0.001$ \\
\hline Radioactive material & 70 & 37 & 4.9 & 33 & 2.9 & 0.023 \\
\hline Garbage & 62 & 31 & 4.1 & 31 & 2.7 & 0.091 \\
\hline Occupational stress & 376 & 172 & 22.6 & 204 & 17.7 & 0.009 \\
\hline Biological material & 52 & 33 & 4.4 & 19 & 1.7 & $<0.001$ \\
\hline Industrial dust & 421 & 172 & 22.8 & 249 & 21.8 & 0.621 \\
\hline Total & 1,910 & 761 & 39.8 & 1,149 & 60.2 & \\
\hline
\end{tabular}

* Frequency adjusted by sample complex design;

** Chi-squared test;

*** Social class according to the Brazilian criteria of economic classification 6 . Average household income in 2015: A/B, USD 6,500-USD 1,419; C, USD 463-USD 772; D/E, USD 205. 
Health-related quality of life scores for all five dimensions were mostly reported as good (without any problem). For formal workers, the mean utility score was 0.907 (95\%CI: 0.899; 0.915); for informal workers, it was 0.882 (95\%CI: $0.874 ; 0.889)$. The mean utility score for both informal and formal workers was 0.886 (95\%CI: $0.881 ; 0.890)$. Informal workers reported better health statuses in mobility (96.1\% vs. $92.8 \%$ ) and pain/discomfort (63.7\% vs. 56.6\%) dimensions in comparison to formal workers. The dimensions with higher proportion of individuals with bad statuses were pain/discomfort and anxiety/depression (Table 2).

In the adjusted analysis, informal workers' had a higher chance of reduced quality of life by exposure to noise $(\mathrm{OR}=1.28 ; 95 \% \mathrm{CI}: 1,13 ; 1.52)$, occupational stress (OR = 1.95; 95\%CI: 1.65; 2.21), and industrial dusts $(\mathrm{OR}=1.46$; 95\%CI: 1.28; 1.72), when compared to absence of this exposure (Table 3). The quality of life of formal workers was negatively impacted by exposure to chemical substances $(\mathrm{OR}=1.58 ; 95 \% \mathrm{CI}: 1.28 ; 1.87)$, noise $(\mathrm{OR}=1.40 ; 95 \% \mathrm{CI}: 1.23 ; 1.65)$, sun $(\mathrm{OR}=1.65 ; 95 \% \mathrm{CI}$ : 1.09; 1.40), occupational stress ( $\mathrm{OR}=1.65$; 95\%CI: 1.46; 1.87), biological material (OR = 2.61; 95\%CI: 1.72; $3.97)$, and industrial dusts $(\mathrm{OR}=1.46$; $95 \% \mathrm{CI}: 1.28 ; 1.65)$. Formal workers had a higher chance of better quality of life in the presence of exposure to radioactive material $(\mathrm{OR}=0.58 ; 95 \% \mathrm{CI}: 0.38 ; 0.92)$.

Table 2

Characteristics of each domain of the European Quality of Life 5-Dimensions 3-Levels (EQ-5D-3L) of all workers, stratified by formality in the Manaus Metropolitan Region, Amazonas State, Brazil, $2015(N=1,910)$.

\begin{tabular}{|c|c|c|c|c|c|c|}
\hline \multirow[t]{2}{*}{ EQ-5D-3L domain } & \multicolumn{2}{|c|}{ All workers } & \multicolumn{2}{|c|}{ Informal worker } & \multicolumn{2}{|c|}{ Formal worker } \\
\hline & $\mathbf{n}$ & $\%$ * & $\mathbf{n}$ & $\%$ * & $\mathbf{n}$ & $\%$ * \\
\hline \multicolumn{7}{|l|}{ Mobility } \\
\hline No problems & 1,797 & 94.1 & 731 & 96.1 & 1,066 & 92.8 \\
\hline Some problems & 111 & 5.8 & 30 & 3.9 & 81 & 7.0 \\
\hline Confined to bed & 2 & 0.1 & 0 & 0.0 & 2 & 0.2 \\
\hline \multicolumn{7}{|l|}{ Self-care } \\
\hline No problems & 1,864 & 97.6 & 748 & 98.3 & 1,116 & 97.1 \\
\hline Some problems & 44 & 2.3 & 13 & 1.7 & 31 & 2.7 \\
\hline Extreme problem & 2 & 0.1 & 0 & 0.0 & 2 & 0.2 \\
\hline \multicolumn{7}{|l|}{ Usual activities } \\
\hline No problems & 1,859 & 97.3 & 742 & 97.5 & 1,117 & 97.2 \\
\hline Some problems & 50 & 2.6 & 19 & 2.5 & 31 & 2.7 \\
\hline Extreme problem & 1 & 0.0 & 0 & 0.0 & 1 & 0.1 \\
\hline \multicolumn{7}{|l|}{ Pain/Discomfort } \\
\hline None & 1,138 & 59.5 & 486 & 63.7 & 652 & 56.6 \\
\hline Moderate & 686 & 36.1 & 256 & 33.8 & 430 & 37.6 \\
\hline Extreme & 86 & 4.5 & 19 & 2.5 & 67 & 5.8 \\
\hline \multicolumn{7}{|l|}{ Anxiety/Depression } \\
\hline None & 1,564 & 81.9 & 637 & 83.6 & 927 & 80.7 \\
\hline Moderate & 315 & 16.5 & 118 & 15.6 & 197 & 17.1 \\
\hline Extreme & 31 & 1.6 & 6 & 0.8 & 25 & 2.2 \\
\hline
\end{tabular}

* Frequency adjusted by sample complex design. 
Table 3

Occupational exposures and means of quality of life utility scores calculated by Tobit adjusted regression analysis stratified by formality in the Manaus Metropolitan Region, Amazonas State, Brazil, 2015 ( $\mathrm{N}=1,910)$.

\begin{tabular}{|c|c|c|c|c|}
\hline \multirow[t]{2}{*}{ Occupational exposures } & \multicolumn{2}{|c|}{ Informal worker quality of life * } & \multicolumn{2}{|c|}{ Formal worker quality of life * } \\
\hline & Mean $(95 \% \mathrm{Cl})$ & Tobit coefficient $* *(95 \% \mathrm{CI})$ & Mean $(95 \% \mathrm{Cl})$ & Tobit coefficient ** $(95 \% \mathrm{Cl})$ \\
\hline \multicolumn{5}{|l|}{ Work in the nocturnal period } \\
\hline No & $0.91(0.90 ; 0.92)$ & Reference & $0.88(0.87 ; 0.89)$ & Reference \\
\hline Yes & $0.90(0.88 ; 0.92)$ & $-0.02(-0.06 ; 0.03)$ & $0.88(0.86 ; 0.90)$ & $-0.01(-0.05 ; 0.03)$ \\
\hline \multicolumn{5}{|c|}{ Work for more than 24 consecutive hours } \\
\hline No & $0.91(0.90 ; 0.92)$ & Reference & $0.88(0.88 ; 0.89)$ & Reference \\
\hline Yes & $0.89(0.86 ; 0.92)$ & $-0.03(-0.09 ; 0.04)$ & $0.86(0.83 ; 0.89)$ & $-0.05(-0.10 ; 0.00)$ \\
\hline \multicolumn{5}{|l|}{ Chemical substances } \\
\hline No & $0.91(0.90 ; 0.92)$ & Reference & $0.89(0.88 ; 0.89)$ & Reference \\
\hline Yes & $0.89(0.86 ; 0.91)$ & $-0.05(-0.10 ; 0.01)$ & $0.82(0.79 ; 0.85)$ & $-0.11(-0.15 ;-0.06)$ \\
\hline \multicolumn{5}{|l|}{ Noise } \\
\hline No & $0.92(0.91 ; 0.93)$ & Reference & $0.89(0.88 ; 0.90)$ & Reference \\
\hline Yes & $0.89(0.87 ; 0.90)$ & $-0.06(-0.10 ;-0.03)$ & $0.85(0.84 ; 0.87)$ & $-0.08(-0.12 ;-0.05)$ \\
\hline \multicolumn{5}{|l|}{ Sunlight } \\
\hline No & $0.91(0.90 ; 0.92)$ & Reference & $0.89(0.88 ; 0.90)$ & Reference \\
\hline Yes & $0.89(0.87 ; 0.91)$ & $-0.04(-0.09 ; 0.01)$ & $0.86(0.84 ; 0.87)$ & $-0.05(-0.08 ;-0.02)$ \\
\hline \multicolumn{5}{|l|}{ Radioactive material } \\
\hline No & $0.91(0.90 ; 0.91)$ & Reference & $0.88(0.87 ; 0.89)$ & Reference \\
\hline Yes & $0.95(0.92 ; 0.98)$ & $0.09(-0.01 ; 0.18)$ & $0.93(0.89 ; 0.97)$ & $0.13(0.02 ; 0.23)$ \\
\hline \multicolumn{5}{|l|}{ Garbage } \\
\hline No & $0.91(0.90 ; 0.92)$ & Reference & $0.88(0.88 ; 0.89)$ & Reference \\
\hline Yes & $0.88(0.84 ; 0.92)$ & $-0.05(-0.14 ; 0.03)$ & $0.82(0.77 ; 0.88)$ & $-0.07(-0.15 ; 0.01)$ \\
\hline \multicolumn{5}{|l|}{ Occupational stress } \\
\hline No & $0.92(0.92 ; 0.93)$ & Reference & $0.89(0.88 ; 0.90)$ & Reference \\
\hline Yes & $0.85(0.83 ; 0.86)$ & $-0.16(-0.19 ;-0.12)$ & $0.83(0.81 ; 0.85)$ & $-0.12(-0.15 ;-0.09)$ \\
\hline \multicolumn{5}{|l|}{ Biological material } \\
\hline No & 0.91 (0.90; 0.91) & Reference & $0.88(0.88 ; 0.89)$ & Reference \\
\hline Yes & $0.92(0.89 ; 0.96)$ & $0.02(-0.07 ; 0.12)$ & $0.73(0.65 ; 0.81)$ & $-0.23(-0.33 ;-0.13)$ \\
\hline \multicolumn{5}{|l|}{ Industrial dust } \\
\hline No & $0.92(0.91 ; 0.93)$ & Reference & $0.89(0.88 ; 0.90)$ & Reference \\
\hline Yes & 0.87 (0.86; 0.89) & $-0.09(-0.13 ;-0.06)$ & $0.85(0.83 ; 0.86)$ & $-0.09(-0.12 ;-0.06)$ \\
\hline
\end{tabular}

* Quality of life values were measured by the European Quality of Life 5-Dimensions 3-Levels instrument and transformed as utility values based on values from a previous study in the Brazilian population 8;

** Adjusted by sample complex design, age group, social class and education level.

\section{Discussion}

Informal workers were significantly more exposed to working in nocturnal periods, chemical substances, noise, radioactive material, occupational stress, and biological material, whereas formal workers were more frequently exposed to sun. Health-related quality of life was high among workers, similarly to the general population from the Manaus Metropolitan Region 9.

Recall bias from the self-reporting model may have influenced the results as participants might not remember being exposed to certain occupational risks. Selection bias is also possible since only individuals who were present at their residences during the interview period were invited to participate in the survey. Although the EQ-5D-3L instrument is easy to apply and is currently used in different contexts worldwide for measuring quality of life, its discriminant ability is lower when compared to other specific instruments ${ }^{14}$. Relevant data such as physical activity, religious beliefs, 
chronic diseases, fruit and vegetable consumption, and leisure time were not collected, which may play an important role on quality of life 15 .

The Brazilian Labor Reform approved by the National Congress in 2017, two years after this study was conducted, resulted in significant changes to the employment regulations by allowing employers to determine hiring conditions, use of workforce, and other social rights 16 . This process led to increased insecurity among workers, loss of labor rights, and reduced social protection 16. Empirical evidence from after the implementation of the Labor Reform showed that this act probably impacted workers' health and quality of life 17.

Exposure to noise in occupational settings was negatively associated with the quality of life of both informal and formal workers. A study conducted in 2015 in Belo Horizonte, Minas Gerais State, with professionals working in ambulances found that auditory (tinnitus, intolerance to intense sounds, and aural fulness) and nonauditory symptoms (irritability, headache, difficulty in talking in noisy environments, and sleep alterations) were frequent among these professionals 18 . Preventive measures should be adopted to reduce the risks and improve the quality of life of these workers.

Occupational stress was also a negative factor for the workers' quality of life. A cross-sectional study conducted in Pelotas, Rio Grande do Sul State, in 2012 with community health agents showed that $71 \%$ of the 181 professionals were in a state of stress resistance, $30.5 \%$ were in the alert state of stress, and $32.8 \%$ were in the stress state of exhaustion, which were confirmed by higher salivary cortisol levels. Depressive episodes were observed in $28.2 \%$ of the participants and low scores for quality of life were reported 19 .

Occupational exposure to biological materials and industrial dust were associated with worse quality of life among informal and formal workers. Healthcare professionals are particularly at increased risk of occupational exposure to biological materials since they are frequently in contact with body secretions and can be injured by handling sharp instruments, which may lead to microbiological infections 20. A previous study conducted in Namibia from 2013 to 2014 with 307 workers from charcoal factories showed that exposure to dust was significantly associated with usual cough, usual phlegm, episodes of phlegm and cough, and shortness of breath 21.

Exposure to chemical substances and to sunlight negatively affected the quality of life. Such exposures are risk factors for chronic noncommunicable diseases. A cross-sectional study carried out in 2014 with 545 civil construction workers from Cuiabá, Mato Grosso State, found that the odds of developing respiratory symptoms (e.g., cough) were higher for those exposed to chemicals, such as paint and hydrocarbon solvents 22. A previous cross-sectional study conducted in 2017 with 348 outdoor workers (farmers, gardeners, and mountain guides) and 215 indoor workers (office employees) from Germany found an increased risk of developing non-melanoma skin cancer in outdoor professionals 23 .

Radioactive materials were positively associated with the quality of life of formal workers. Labor protection associated with contracts of workers involved with radiation activities in Brazil may explain these results. A meta-analysis from 2014 investigating the renal effects and carcinogenicity of occupational exposure to uranium in 71,114 workers found a significantly lower tumor risk in the case groups when compared to control groups, and the risk of nephrotoxicity was also not increased 24. This finding contrasts with the results of a previous case-control study conducted in Shanghai, China, from 1987 to 1989, where a significant increase in the risk of leukemia was observed in workers who self-reported exposure to benzene, synthetic fiber dust, toluene, and radioactive materials 25 .

\section{Conclusions}

The exposure to occupational risks among the working population of the Manaus Metropolitan Region is high and affects both informal and formal workers. Quality of life was negatively associated with exposure to noise, occupational stress, industrial dust, chemical substances, sunlight, and biological materials. Health policies and labor rights should be protected and reestablished in Brazil to reduce health inequalities among informal and formal workers, as well as minimize potential risks associated with occupational exposure. 


\section{Contributors}

G. M. B. Tiguman analyzed and interpretated the data of the work and drafted the manuscript. M. Caicedo-Roa analyzed the data of the work and critically revised the manuscript. M. T. Silva and T. F. Galvao designed the work, analyzed and interpretated the data of the work and revised critically the manuscript. All authors approved the version to be published and agree to be accountable for all aspects of the work in ensuring that questions related to the accuracy or integrity of any part of the work are appropriately investigated and resolved.

\section{Additional informations}

ORCID: Gustavo Magno Baldin Tiguman (00000001-9518-7194); Monica Caicedo-Roa (00000001-7313-8260); Marcus Tolentino Silva (00000002-7186-9075); Tais Freire Galvao (0000-00032072-4834).

\section{References}

1. Takala J, Hämäläinen P, Saarela KL, Yun LY, Manickam K, Jin TW, et al. Global estimates of the burden of injury and illness at work in 2012. J Occup Environ Hyg 2014; 11:326-37.

2. Santana VS, Ferrite S, Galdino A, Peres Moura MC, Machado JM. Gathering occupational health data from informal workers: the Brazilian experience. New Solut 2016; 26:173-89.

3. Miquilin IOC, Marín-León L, Monteiro MI, Corrêa Filho HR. Desigualdades no acesso e uso dos serviços de saúde entre trabalhadores informais e desempregados: análise da PNAD 2008, Brasil. Cad Saúde Pública 2013; 29:1392-406.

4. Silva MT, Galvao TF. Use of health services among adults living in Manaus Metropolitan Region, Brazil: population-based survey, 2015. Epidemiol Serv Saúde 2017; 26:725-34.

5. Maciel FT, Oliveira AMHC. Dynamics of the formal and informal labour in Brazil: occupational and earnings mobility. International Journal of Development Issues 2018; 17:28-54.

6. Associação Brasileira de Empresas de Pesquisa. Critério de Classificação Econômica Brasil. http://www.abep.org/criterio-brasil (accessed on 02/Nov/2016).

7. Devlin NJ, Brooks R. EQ-5D and the EuroQol Group: past, present and future. Appl Health Econ Health Policy 2017; 15:127-37.

8. Santos M, Cintra MA, Monteiro AL, Santos B, Gusmao-Filho F, Andrade MV, et al. Brazilian valuation of EQ-5D-3L health states: results from a saturation study. Med Decis Making 2016; 36:253-63.

9. Silva MT, Caicedo Roa M, Galvao TF. Healthrelated quality of life in the Brazilian Amazon: a population-based cross-sectional study. Health Qual Life Outcomes 2017; 15:159.

10. Heeringa SG, Berglund PA, West BT, Mellipilan ER, Portier K. Attributable fraction estimation from complex sample survey data. Ann Epidemiol 2015; 25:174-8.

11. Austin PC, Escobar M, Kopec JA. The use of the Tobit model for analyzing measures of health status. Qual Life Res 2000; 9:901-10.

12. Wu M, Brazier JE, Kearns B, Relton C, Smith C, Cooper CL. Examining the impact of 11 long-standing health conditions on healthrelated quality of life using the EQ-5D in a general population sample. Eur J Health Econ 2015; 16:141-51.

13. Chinn S. A simple method for converting an odds ratio to effect size for use in meta-analysis. Stat Med 2000; 19:3127-31.

14. Yfantopoulos JN, Chantzaras AE. Validation and comparison of the psychometric properties of the EQ-5D-3L and EQ-5D-5L instruments in Greece. Eur J Health Econ 2017; 18:519-31.

15. Vankova D, Kerekovska A, Kostadinova T, Todorova L. Researching health-related quality of life at a community level: results from a population survey conducted in Burgas, Bulgaria. Health Promot Int 2016; 31:534-41. 
16. Krein JD. Dismantling of rights, new configurations of labor and weakening of collective action: the labor reform consequences. Tempo Social 2018; 30:77-104.

17. Costa BS, Costa SS, Cintra CLD. Possible impacts of the labor law reform on workers' health. Rev Bras Med Trab 2018; 16:109-17.

18. Oliveira RC, Santos JN, Rabelo ATV, Magalhaes MC. The impact of noise exposure on workers in Mobile Support Units. Codas 2015; 27:215-22.

19. Knuth BS, Cocco RA, Radtke VA, Medeiros JR, Oses JP, Wiener CD, et al. Stress, depression, quality of life and salivary cortisol levels in community health agents. Acta Neuropsychiatr 2016; 28:165-72.

20. Balsamo AC, Felli VE. Study of work accidents related to human body fluids exposure among health workers at a university hospital. Rev Latinoam Enferm 2006; 14:346-53.

21. Hamatui N, Naidoo RN, Kgabi N. Respiratory health effects of occupational exposure to charcoal dust in Namibia. Int J Occup Environ Health 2016; 22:240-8.
22. da-Silva-Filho P, Botelho C, Castro H, Ferreira M, Silva A. Prevalência e fatores associados a sintomas respiratórios em trabalhadores da construção civil: uma proposta de vigilância em saúde do trabalhador. Rev Bras Med Trab 2019; 17:119-29.

23. Zink A, Tizek L, Schielein M, Böhner A, Biedermann T, Wildner M. Different outdoor professions have different risks: a cross-sectional study comparing non-melanoma skin cancer risk among farmers, gardeners and mountain guides. J Eur Acad Dermatol Venereol 2018; 32:1695-701.

24. Stammler L, Uhl A, Mayer B, Keller F. Renal effects and carcinogenicity of occupational exposure to uranium: a meta-analysis. Nephron Extra 2016; 6:1-11.

25. Adegoke OJ, Blair A, Shu XO, Sanderson M, Jin F, Dosemeci M, et al. Occupational history and exposure and the risk of adult leukemia in Shanghai. Ann Epidemiol 2003; 13:485-94. 


\section{Resumo}

O estudo buscou investigar a associação entre exposições ocupacionais e qualidade de vida relacionada à saúde entre trabalhadores informais e formais na Amazônia brasileira. Realizamos um estudo transversal com trabalhadores adultos na Região Metropolitana de Manaus, Amazonas, em 2015. Os participantes foram selecionados por amostragem probabilística em três estágios. O desfecho primário foi a qualidade de vida relacionada à saúde, medida pela versão brasileira validada do instrumento European Quality of Life 5Dimensions 3-Levels (EQ-5D-3L). Foi realizada a análise multivariada ajustada por regressão de Tobit, considerando o desenho complexo da amostra. Os resultados foram convertidos em razão de chances (OR). Entre os 1.910 individuos na amostra que estavam trabalhando, 60,2\% eram trabalhadores formais. Os trabalhadores informais foram mais expostos aos riscos ocupacionais ( $p \leq 0,05)$. A média de utilidade para trabalhadores informais e formais foi 0,886 (IC95\%: 0,881; 0,890). A qualidade de vida dos trabalhadores informais foi impactada negativamente pela exposição ao ruído $(O R=1,28$; IC95\%: 1,13; 1,52), estresse ocupacional (OR = 1,95; IC95\%: 1,65; 2,21) e poeiras industriais $(O R=1,46$; IC95\%: $1,28 ; 1,72)$, enquanto trabalhadores formais mostraram uma associação negativa com exposição a substâncias químicas (OR = 1,58; IC95\%: 1,28; 1,87), ruido (OR = 1,40; IC95\%: 1,23; 1,65), luz solar $(O R=1,65$; IC95\%: 1,09; 1,40), estresse ocupacional $(O R=1,65 ;$ IC95\%: 1,46; 1,87), material biológico $(O R=2,61$; IC95\%: 1,72; 3,97) e poeiras industriais $(O R=1,46$; IC95\%: 1,28; 1,65). A exposição a riscos ocupacionais entre trabalhadores na Região Metropolitana de Manaus é alta, afetando trabalhadores informais e formais. Politicas brasileiras devem ser implementadas para reduzir os impactos sobre a qualidade de vida dos trabalhadores nessa região do país.

Riscos Ocupacionais; Exposição Ocupacional; Saúde do Trabalhador; Qualidade de Vida

\section{Resumen}

El objetivo era investigar la asociación entre exposiciones ocupacionales y calidad de vida relacionada con la salud entre trabajadores formales $e$ informales en la Amazonia Brasileña. Realizamos un estudio transversal con trabajadores adultos en la región metropolitana de Manaus, estado del Amazonas, en 2015. Los participantes fueron seleccionados a través de una muestra probabilistica en tres pasos. El resultado primario fue la calidad de vida relacionada con la salud, medida por la versión brasileña validada de la herramienta European Quality of Life 5-Dimensions 3-Levels (EQ-5D-3L). Se realizó un análisis ajustado multivariado mediante la regresión Tobit y se consideró el diseño complejo de la muestra. Los resultados se convertieron en odds ratio (OR). De los 1.910 trabajadores procedentes de la muestra, un 60,2\% fueron trabajadores formales. Los trabajadores informales estuvieron significativamente más expuestos a los riesgos ocupacionales que los trabajadores formales $(p \leq 0,05)$. La puntuación media de utilidad para los trabajadores informales $y$ formales fue 0,886 (IC95\%: 0,881; 0,890). La calidad de vida de los trabajadores informales estuvo negativamente impactada por la exposición al ruido $(O R=1,28 ;$ IC95\%: 1,13; 1,52), estrés ocupacional $(O R=1,95$; IC95\%: 1,65; 2,21), y polvos industriales $O R=1,46$; IC95\%: 1,28; 1,72), mientras que los trabajadores formales estuvieron negativamente asociados con la exposición a sustancias químicas $(O R=1,58$; IC95\%: 1,28; 1,87), ruido $(O R=1,40$; IC95\%: 1,23; 1,65), sol $(O R=1,65$; IC95\%: 1,09; 1,40), estrés ocupacional $(O R=1,65$; IC95\%: 1,46; 1,87), material biológico $(O R=2,61$; IC95\%: 1,72; 3,97), y polvos industriales $(O R=1,46$; IC95\%: 1,$28 ; 1,65)$. La exposición a riesgos ocupacionales entre trabajadores en la región metropolitana de Manaus es alta, afectando tanto a trabajadores informales como formales. Se necesitan imponer politicas brasileñas para reducir los impactos en la calidad de vida entre trabajadores en esta región.

Riesgos Laborales; Exposición Profesional; Salud Laboral; Calidad de Vida
Submitted on 08/Apr/2020

Final version resubmitted on 04/Sep/2020

Approved on 31/Oct/2020 